\title{
Sexual health education- is it still a taboo? A survey from an urban school in Puducherry
}

\author{
Jayasree Manivasakan*, Sindhu Sankaran
}

\begin{abstract}
Department of Obstetrics and Gynaecology, Sri Manakula Vinayagar Medical College and Hospital, Kalitheerthalkuppam, Puducherry, India
\end{abstract}

Received: 14 January 2014

Accepted: 2 February 2014

\section{*Correspondence:}

Dr. Jayasree Manivasakan,

E-mail: drmjayasree1@yahoo.co.in

(C) 2014 Manivasakan $\mathrm{J}$ et al. This is an open-access article distributed under the terms of the Creative Commons Attribution Non-Commercial License, which permits unrestricted non-commercial use, distribution, and reproduction in any medium, provided the original work is properly cited.

\section{ABSTRACT}

Background: Children need facts about sexuality and reproductive health in order to protect themselves and others. They need positive reinforcement, positive self-esteem and the confidence to make responsible decisions. This survey was conducted in an urban school in Puducherry to assess the parent's attitude towards sexual health education for adolescents.

Methods: The questionnaire was distributed when the parents came for open school day and was returned by the parents after one week to their children's class teacher. The questionnaire consisted of two sections. The first section elicited respondents biographical information i.e. age, level of education and religion. The second section compromised questions on the attitude about sexual health education in schools. The data was analyzed using epi info version 3.5 and results expressed in percentage.

Results: The mean age of the mother participated the study is 40years. The mean age of the father is 47 years. In our study $94.5 \%$ of parents wanted sexual health education (SHE) to be started in school, $4.5 \%$ from college and $1 \%$ don't want SHE. Parents who opted for SHE from school, 58.9\% wanted to start from high school, 27.2\% from higher secondary school and $8.5 \%$ from primary school. SHE should be taught by health professionals were opined by $38.1 \%$, by parents $8.5 \%$, by teachers $24.4 \%$ and by all $8.8 \%$. While $41.5 \%$ were willing for all the topics to be taught, $19.9 \%$ opined for emotional changes and only $5.6 \%$ for sexual abuse.

Conclusion: A sensitization program for parents about sexual health education may improve their attitude.

Keywords: Parents, Sexual health education, Sexual abuse

\section{INTRODUCTION}

Young people live in a world riddled with HIV/AIDS, illicit behavior, drugs, incest, rape, crimes, unintended pregnancies and much more. Most parents are uneasy talking with young people about such issues. Children need facts about sexuality and reproductive health in order to protect themselves and others. They need positive reinforcement, positive self-esteem and the confidence to make responsible decisions. In Tamilnadu and Puducherry anatomical and physiological changes during adolescent period and drug abuse and sexual abuse are dealt with from eighth standard as part of Samacheer kalvi thittam in schools. This study was done as a part of educating the girls after the incidence of infamous rape case of Delhi to sensitize the girls. Since most of the perpetrators of rape were known to the victims they were educated about preventive measures. Before the talk consent was got from the parents. This study shows the parents attitude towards sexual health education in schools.

\section{METHODS}

A survey was done in parents of children who attended an urban all girls school. This study was done among parents 
of students belonging to class of ninth standard and eleventh standard. Tenth and twelfth classes were excluded from the study because they were preparing for their board exams. The questionnaire was distributed when the parents came for open school day i.e. is when the parents can meet their wards teachers to discuss about their progression in studies as well as extracurricular activities. The questionnaire was returned by the parents after one week to their children's class teacher. The questionnaire consists of two sections. The first section elicited respondents biographical information i.e. age, level of education and religion. The second section compromised questions on the attitude about sexual health education in schools.

The data was analyzed using epi info version 3.5 and results expressed using descriptive statistics.

\section{RESULTS}

Table 1: Best start for sexual health education.

\begin{tabular}{|lll|}
\hline $\begin{array}{l}\text { Sexual health education } \\
\text { should start from }\end{array}$ & Frequency & Percent \\
\hline College & 14 & $4.5 \%$ \\
\hline High school & 182 & $58.9 \%$ \\
\hline Higher secondary & 84 & $27.2 \%$ \\
\hline None & 3 & $1.0 \%$ \\
\hline Primary & 26 & $8.4 \%$ \\
\hline Total & 309 & $100.0 \%$ \\
\hline
\end{tabular}

Table 2: Recommended sexual health educator for adolescents.

\begin{tabular}{|lll|}
\hline $\begin{array}{l}\text { Sexual health education } \\
\text { should be taught by }\end{array}$ & Frequency & Percent \\
\hline 1-parents & 27 & $8.73 \%$ \\
\hline 2-teachers & 75 & $24.27 \%$ \\
\hline 3-health profess & 117 & $37.86 \%$ \\
\hline 4-peer group & 1 & $0.3 \%$ \\
\hline 5- 1,2,3 & 30 & $9.7 \%$ \\
\hline 6-1\&2 & 25 & $8.1 \%$ \\
\hline 7-1\&3 & 8 & $2.58 \%$ \\
\hline 9-2,3 & 26 & $8.41 \%$ \\
\hline Total & 309 & $100.0 \%$ \\
\hline
\end{tabular}

The mean age of the mother participated the study is 40 years. The mean age of the father is 47 years. In our study $94.5 \%$ of parents wanted sexual health education (SHE) to be started in school, $4.5 \%$ from college and $1 \%$ don't want SHE. Parents who opted for SHE from school, $58.9 \%$ wanted to start from high school, $27.2 \%$ from higher secondary school and $8.5 \%$ from primary school. SHE should be taught by health professionals were opined by $38.1 \%$, by parents $8.5 \%$, by teachers $24.4 \%$ and by all $8.8 \%$. While $41.5 \%$ were willing for all the topics to be taught, $19.9 \%$ opined for emotional changes and only $5.6 \%$ for sexual abuse. Majority of the parents (72\%) thought that SHE won't encourage teens to have premarital sex while $12 \%$ of parents opined yes and $16.5 \%$ of parents as don't know. Parents acknowledged $(72.16 \%)$ that they should make it easy for their children to talk to them about sex.

Table 3: Recommended source of knowledge of SHE for adolescents.

\begin{tabular}{|lll|}
\hline Advice & Frequency & Percent \\
\hline 1-Telephone help lines & 2 & $0.6 \%$ \\
\hline 2 -internet & 5 & $1.6 \%$ \\
\hline 3 -books & 18 & $5.8 \%$ \\
\hline $\begin{array}{l}4-\text { health education } \\
\text { classes }\end{array}$ & 264 & $85.4 \%$ \\
\hline 5 -all & 3 & $1.0 \%$ \\
\hline 6 -1,3,4 & 4 & $1.3 \%$ \\
\hline $7-3,4$ & 11 & $3.6 \%$ \\
\hline 9 -1,4 & 2 & $0.6 \%$ \\
\hline Total & 309 & $100.0 \%$ \\
\hline
\end{tabular}

Table 4: Topics for sexual health education.

\begin{tabular}{|lll|}
\hline $\begin{array}{l}\text { Sexual health education } \\
\text { should include }\end{array}$ & Frequency & Percent \\
\hline 1-physical changes & 21 & $6.8 \%$ \\
\hline 2-emotional changes & 61 & $19.7 \%$ \\
\hline 3-biology of reproduction & 29 & $9.4 \%$ \\
\hline 5-STD & 8 & $2.6 \%$ \\
\hline 6-family values & 5 & $1.6 \%$ \\
\hline 7-positive attitude & 12 & $3.9 \%$ \\
\hline 8-sexual abuse & 16 & $5.2 \%$ \\
\hline 9-all & 130 & $42 \%$ \\
\hline $10-1,2$ & 18 & $5.8 \%$ \\
\hline 11-1,2,3 & 9 & $2.9 \%$ \\
\hline Total & 309 & $100.0 \%$ \\
\hline
\end{tabular}


Table 5: Education qualification of parents.

\begin{tabular}{|lllll|}
\hline \multicolumn{3}{|c}{ Mother } & \multicolumn{3}{c|}{ Father } \\
\hline $\begin{array}{l}\text { Education } \\
\text { qualification }\end{array}$ & Frequency & Percent & Frequency & Percent \\
\hline $1-$ illiterate & 3 & $1.0 \%$ & 6 & $1.94 \%$ \\
\hline $\begin{array}{l}3 \text {-high } \\
\text { school }\end{array}$ & 35 & $11.3 \%$ & 39 & $12.6 \%$ \\
\hline $\begin{array}{l}4-\text {-higher } \\
\text { secondary } \\
\text { school }\end{array}$ & 49 & $15.8 \%$ & 31 & $10 \%$ \\
\hline $\begin{array}{l}6- \\
\text { undergraduate } \\
\text { degree }\end{array}$ & 134 & $43.3 \%$ & 136 & $44 \%$ \\
\hline $\begin{array}{l}7- \\
\text { postgraduate } \\
\text { degree }\end{array}$ & 88 & $28.47 \%$ & 97 & $31.3 \%$ \\
\hline Total & 309 & $100.0 \%$ & 309 & $100.0 \%$ \\
\hline
\end{tabular}

\section{DISCUSSION}

Adolescent's sexual attitude and behavior are largely influenced by parents. They also influence the school based sexual education. In India the word sex is taboo and anything related towards it is looked upon suspiciously.

In our study $94.5 \%$ of parents wanted sexual health education (SHE) to be started in school which correlates with Canadian study where $94 \%$ of parents either agreeing $(40 \%)$ or strongly agreeing $(54 \%)$ that SHE should be provided in school. ${ }^{1}$ Half of the parents $(58.9 \%)$ wanted sexual health education (SHE) to be started from high school followed by higher secondary school by $28 \%$ of patients. Only $8.4 \%$ of parents wanted SHE to be started from primary school which is in contrast to a study from Canada where $65 \%$ of parents wanted SHE to be started from primary school. ${ }^{1}$ Parents believe that some aspects of sexuality and relationships education should be taught even before children start primary school ${ }^{2}$ with the majority of subjects covered in the middle years. ${ }^{3}$ But in our society, children are confronted with sexual images in advertisement and in the media. According to Personal Social Health and Economic Education association (PSHE). ${ }^{4}$ SHE in primary schools prepares children for secondary school where learning will broaden to include human reproduction, contraception, pregnancy, sexually transmitted infections and HIV. In reception and key stage 1, children might learn about their special people; friends and friendship; learning to recognise and react to different feelings and how to keep safe. When they are 67 years old, they will explore the different stages of human development, understanding how some people's needs and responsibilities stay the same whilst some change as they get older. Towards the end of their time in primary school children learn the process of conception and understand the importance of loving, stable relationships and revisiting differences in reproductive system between boys and girls, they learn how they change during puberty.

In our study parents wanted doctors and teachers to be involved in imparting SHE which is in contrast to other studies where parents support their teachers to provide comprehensive SHE in schools. ${ }^{5}$ Only one fourth of parents wanted to be involved in imparting SHE in our study. But in a study conducted in Ludhiana district of Punjab, $80 \%$ of the parents agreed that they should be the first teacher about SHE. ${ }^{6}$

In our study sixty percent of parents don't want their children to know about contraception. In a study about parental attitude about SHE in Malaysia $45 \%$ of parents agreed that birth control should be part of SHE. ${ }^{7}$ The USbased National Campaign to Prevent Teen and Unplanned Pregnancy conducted a review of 115 sex education programs in $2007^{8}$ and found that $60 \%$ of the comprehensive programs that include both abstinence and contraception reduced unprotected sex and delayed initiation of sex. More than $90 \%$ of the parents wanted SHE through health education classes and less than $10 \%$ wanted their children to know about SHE through telephone help lines, internet and books. In a crosssectional survey in Mumbai, more than $60 \%$ of the adolescents preferred doctors for advice on contraception and sexual health. ${ }^{9}$

When asked whether SHE will increase premarital sex, $12 \%$ of the parents have answered yes, $72 \%$ no and $16 \%$ as don't know.

In our study $88 \%$ of parents who wanted all topics (physical changes, emotional changes, Sexually transmitted diseases, contraception, sexual abuse, positive attitude to deal with changes and conception) their educational qualification is a college degree. This correlates with a study among eleventh standard students of nine schools across Pondicherry, where students were selected by random sampling technique and awareness of HIV was tested by questionnaire the students knowledge was good and factors which has influenced better scores were parents with educational qualification of degree and urban location. ${ }^{10}$

Apart from $42 \%$ of parents who felt that all topics should be covered in SHE only another $5 \%$ of parents wanted topics about preventing sexual abuse to be taught to their children in our study. A study done by save the children and TULIR among school going children in Chennai, Tamilnadu $42 \%$ of children have faced one form of sexual abuse or the other. ${ }^{11}$

The prevention-education programs cannot prevent the prevent the occurrence of sexual victimization but it can create a more-sensitive environment among adults, other children, and organizations in general to respond to and help child victims. ${ }^{12,13}$ It also helps to promote disclosure 
by victims. It also prevents the negative outcomes subsequent to victimization such as guilt feelings, selfblame, and shame. ${ }^{14}$

\section{Limitations}

This was a survey conducted in only one school. So the results can't be generalized. The study relied only on questionnaire for data collection therefore may lack understanding which would have been gained through interviews.

\section{CONCLUSION}

A comprehensive sexual health education programme should exist in schools and parents should play a major role in it. A sensitizing programme about sexual health education to parents can improve their attitude.

Funding: No funding sources Conflict of interest: None declared

Ethical approval: Not required

\section{REFERENCES}

1. Weaver AD, Byers SE, Sears HA, Cohen J, Randal HES. Sexual health education at school and at home: attitudes and experiences of New Brunswick parents. The Canadian Journal of Human Sexuality 2002;11:19-31.

2. Galaxy research. (2008). Sexuality education study. Brisbane: Internal polling document prepared for Family Planning Queensland.

3. Eisenberg M.E, Bernat DH, Bearinger LH, Resnick MD. Support for comprehensive sexuality education: Perspectives from parents of school-age youth. Journal of Adolescent Health 2008;42(4):352-9.

4. www.pshe-association.org.uk.
5. Footprints market research. (2011). Attitudes of parents and carers towards sexuality and relationships education in schools. Brisbane: Internal polling document prepared for Family Planning Queensland.

6. A study of the attitude of teachers, parents and adolescents towards sex education MIER Journal of Educational Studies, Trends \& Practices November 2012;2(2):177-89.

7. Parents' Attitudes towards Inclusion of Sexuality Education in Malaysian Schools. International Journal about Parents in Education Copyright 2009 by European Network about Parents in Education 2009, Vol. 3, No. 1, 42-56.

8. Kirby, Douglas, Ph. D. "Emerging Answers". November 2007. http://www.thenationalcampaign. org/EA2007/.

9. Benzaken, et al. Exposure to and opinions towards sex education among adolescent students in Mumbai: A cross sectional survey. BMC Public Health 2011;11:805.

10. AIDS awareness among XI standard students in Pondicherry Region. Indian Journal of Applied Research 2013;3(5).

11. Save the Children and Tulir (2006): Research on Prevalence and Dynamics of Child Sexual Abuse among school going children in Chennai.

12. Finkelhor D. Prevention of sexual abuse through educational programs directed toward children. Pediatrics 2007;120(3):640-5.

13. Finkelhor D, Asdigian N, Dziuba-Leatherman J. The effectiveness of victimization prevention instruction: an evaluation of children's responses to actual threats and assaults. Child Abuse Negl. 1995; 19:141-53.

14. Andrews B. Bodily shame as a mediator between abusive experiences and depression. J Abnorm Psychol. 1995;104:277-85.

DOI: $10.5455 / 2320-1770 . i j r \operatorname{cog} 20140331$

Cite this article as: Manivasakan J, Sankaran S.

Sexual health education- is it still a taboo? A survey from an urban school in Puducherry. Int J Reprod Contracept Obstet Gynecol 2014;3:158-61. 